\title{
Differences between Deciduous and Evergreen Broad-leaved Trees in the Pattern of Seasonal Change of Leaf-scale Photosynthetic Net Assimilation Rate and Transpiration Rate.
}

\author{
Kosugi, Yoshiko, Shibata, Syozo, Matsui, Katsutoshi, Kobashi, Sumiji \\ 落葉広葉樹および常緑広葉樹の個葉レベルでの光合成 \\ および蒸散速度の季節変動特性の違い \\ 小杉緑子・柴田昌三・松井勝敏・小橋澄治 \\ Summary
}

\begin{abstract}
Field observations were carried out to compare the diurnal and seasonal pattern of net assimilation rate and transpiration rate of leaves of several evergreen broad-leaved trees and deciduous broad-leaved trees. The patterns of the seasonal changes of net assimilation rate, transpiration rate and stomatal conductance were different between deciduous trees and evegreen trees. The net assimilation rate and stomatal conductance of the deciduous trees peaked in early spring and declined rapidly after summer. The evergreen trees had a relatively low net assimilation rate and stomatal conductance with quite suitable environmental conditions in spring, and the decline after summer was less than that of deciduous trees. These differences in pattern correspond to the differences in the pattern of the seasonal change of leaf greenness which is considered to have close relationship between leaf chlorophyll content.
\end{abstract}

\section{Introduction}

Recently, results of simultaneous observations of photosynthetic net assimilation rate and transpiration rate have been reported for several temperate evergreen and deciduous broad-leaved trees. MASUDA et al. (1991) investigated the characteristics of photosynthesis and transpiration of Cinnamomum camphora Sieb. at different soil conditions and found a considerable difference in the maximum values of net assimilation rate and transpiration rate in summer between poor growth and good growth trees. These variations are considered to be caused by the difference in the distributions of the root systems. SHIBATA et al. (1991) reported the seasonal change of net assimilation rate and transpiration rate of Cinnamomum camphora, Quercus glauca Thunb. and Pasania edulis Nakai, and the influence of air temperature and soil

Key words : photosynthesis, transpiration, stomatal conductance, deciduous trees, evergreen trees, SPAD value. キーワード : 光合成, 蒸散, 気孔コンダクタンス, 落葉樹, 常緑樹, SPAD 值

Graduate School of Agric., Kyoto University

京都大学大学院農学研究科 
moisture conditions to the net assimilation rate and the stomatal conductance of Cinnamomum camphora and Quercus mirsinaefolia Bl.. MASUDA et al. (1994) reported the seasonal changes of net assimilation rate and transpiration rate of Liriodendron tulipifera $\mathrm{L}$. planted on different soil conditions. KOBAYASHI et al. (1995) reported the effects of flooding on water relations and photosynthesis of Prunus $\times$ yedoensis Matsum, Quercus serrata Thunb. and Populus alba L.. HAN and KAKUBARI (1995) observed the diurnal and seasonal change of net assimilation rate, transpiration rate and water-use efficiency of Malus pumila Mill. and Robinia pseudoacacia L. in different soil moisture conditions. These results show the characteristics of both of the maximum value and of the pattern of diurnal and seasonal change of net assimilation rate and transpiration rate for each species, and seem to indicate that the deviations caused by the differences in soil moisture conditions and the distribution of root system is considerably large.

Net assimilation rate and transpiration rate of plants are influenced both by the environmental conditions and plant physiological conditions. To explain the results of observation, these factors must be divided and numerically analyzed. Using the same observation result as SHIBATA et al. (1991), KosUGI et al. (1994) numerically analyzed the determination factors of diurnal and seasonal changes of net assimilation rate, transpiration rate and water-use efficiency using the concepts of stomatal conductance and internal conductance. Kosugi and Kobashi (1994) found out the same tendency as Kosugi et al. (1994) using another data set, and also pointed out the relationships between PAR (photosynthetically active radiation) and both stomatal conductance and internal conductance. KosUGI et al. (1995) simulated the stomatal conductance from PAR, air temperature and vapor pressure deficit using an empirical model and could reproduce the observational results.

In order to estimate the pattern of diurnal and seasonal change of net assimilation rate and transpiration rate in long-term, characterization of plant physiological conditions is needed. However, it has been very difficult to extract such information from different series of observations which have been reported, as net assimilation rate and transpiration rate of plants are dependent upon environmental and physiological conditions. One of the important physiological conditions which might influence gas exchange processes of tree species is the difference between evergreen trees and deciduous trees. However, there is no field observations which observed the diurnal and seasonal change of net assimilation rate and transpiration rate of evergreen trees and deciduous trees simultaneously. In this study, field observations were carried out to compare the diurnal and seasonal pattern of net assimilation rate and transpiration rate of leaves of several evergreen broad-leaved trees and deciduous broad-leaved trees.

\section{Material and methods}

Observations were carried out in a green surrounding of the main building of the Faculty of Agriculture of Kyoto University, located at 35.02 N, $135.47 \mathrm{E}$, at an altitude of $60 \mathrm{~m}$ a.m.s.l., from April 1994 to March 1995. The materials were three temperate evergreen broad-leaved trees (Quercus glauca, Cinnamomum camphora., Pasania edulis) and four temperate deciduous broad-leaved trees (Platanus orientalis L., Liriodendron tulipifera, Prunus $\times$ yedoensis, Cercidiphyllum japonicum Sieb. et Zucc.). Most of these trees were planted or moved to the site in 1956 when the green was renovated, with the exception of the Cinnamomum camphora, which had been planted many years before 1956, and Cercidiphyllum japonicum, which was planted several years after 1956. The green has a very thin zone of surface soil of about 50 $\mathrm{cm}$, under which lies a zone of much harder soil. It is guessed that only the root systems of Cinnamomum camphora penetrate into this older zone. Table 1 and Fig. 1 show the size of the investigated trees and a photograph of the observation site, respectively.

Net assimilation rate, transpiration rate, PAR (photosynthetically active radiation), air and leaf temperature, relative humidity and ambient $\mathrm{CO}_{2}$ concentration on two intact leaves from each of the seven trees were measured hourly from early morning to sunset on 2 May, 28 May, 29 June, 13 July, 25 August, 21 September, 15 October, 29 October, 9 November, 19 November, 22 December 1994 and 26 January, 23 February, 21 March 1995 using the LI-6200 (Li-Cor Inc., Lincoln, Nebraska, USA). Stomatal conductance, PAR, air and leaf temperature and relative humidity on two intact leaves from each of the 
Table 1 Size of the investigated trees.

\begin{tabular}{lccc}
\hline \multicolumn{1}{c}{ Species } & Height $(\mathrm{cm})$ & D.B.H. $(\mathrm{cm})$ & Crown projection $\operatorname{area}^{2}\left(\mathrm{~m}^{2}\right)$ \\
\hline Quercus glauca & 554 & 4.8 & 8.533 \\
Cinnamomum camphora & 1380 & 64.5 & 47.697 \\
Pasania edulis & 378 & 7.6 & 5.306 \\
Platanus orientalis & 686 & 15.4 & 19.339 \\
Liriodendron tulipifera & 1630 & 21.0 & 22.583 \\
Prunus $\times$ yedoensis & 576 & 21.5 & 32.143 \\
Cercidiphyllum japonicum & 825 & 12.4 & 13.602 \\
\hline
\end{tabular}

(October, 1995)

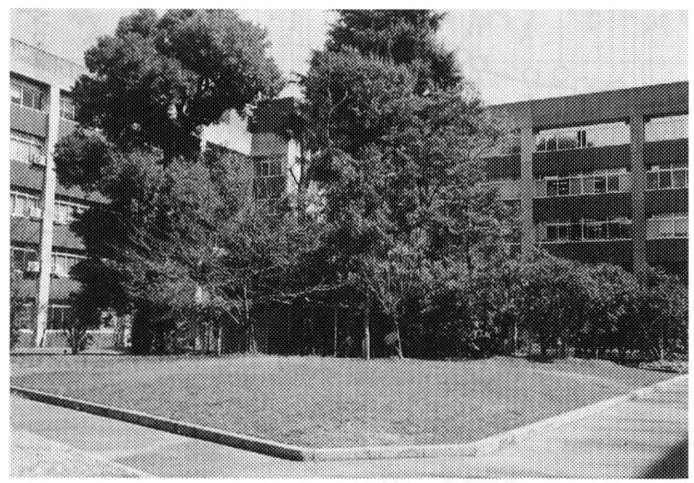

Fig. 1 Photograph of the observation site.

seven trees were measured hourly or 30-minute intervals from early morning to sunset on 21 April, 30 April, 2 May, 23 May, 24 May, 28 May, 7 June, 22 June, 29 June, 13 July, 22 July, 11 August, 25 August, 30 August, 21 September, 30 September, 15 October, 18 October, 29 October, 9 November, 19 November, 30 November, 22 December 1994 and 26 January, 23 February, 21 March 1995 using the LI-1600 (Li-Cor Inc.).

Soil moisture condition was measured using tensiometers. Soil water capillary pressure was measured daily at $10 \mathrm{~cm}, 30 \mathrm{~cm}$ and $50 \mathrm{~cm}$ below the soil surface. Soil was sampled in a $100 \mathrm{cc}$ soil sampler with undisturbed condition to obtain the relationship between capillary pressure head and volumetric water content. Precipitation was measured using a tipping-bucket rain gauge located near the observation site.

To obtain an index of the chlorophyll $\mathrm{a}+\mathrm{b}$ concentration, leaf greenness (SPAD value) was measured using SPAD-502 (Minolta Co.) weekly on five random points of five random intact leaves from each of the seven trees. The SPAD value is an index value representing the difference of absorption by the leaf of two light waves which peak at $650 \mathrm{~nm}$ and $940 \mathrm{~nm}$. It has been reported that the SPAD value has a high linear relationship with chlorophyll $\mathrm{a}+\mathrm{b}$ concentration in leaf and that each species has its own coefficient of the relationship (e.g., MASUdA and IsHi, 1985; ToBias et al., 1994; YoshiKaWA et al., 1994). In this study the SPAD value is used to know the relative seasonal change of chlorophyll concentration of leaf.

\section{Results and Discussion}

\subsection{Soil, air, and plant conditions}

Fig. 2 shows the relationship between the soil water capillary pressure head $\left(\psi_{s}\right)$ and the volumetric soil water content $(\theta)$ of the soil sampled with undisturbed condition from $0 \mathrm{~cm}$ to $5 \mathrm{~cm}$ below the surface of the observation site. This relationship was obtained from the $\mathrm{pF}$-test in laboratory. The line shows the fitted curve using the following function representing the $\theta-\psi_{s}$ relationship, developed by KosUGI, K. 
(1994) based on VAN GENUCHTEN (1980),

$$
\begin{array}{ll}
\left(\theta-\theta_{r}\right) /\left(\theta_{s}-\theta_{r}\right)=\left\{1+m\left(\frac{\phi_{c}-\psi_{s}}{\psi_{c}}-\psi_{0}\right)^{1 /(1-m)}\right\}^{-m} & \left(\psi_{s}<\psi^{\prime}\right) \\
\left(\theta-\theta_{r}\right) /\left(\theta_{s}-\theta_{r}\right)=1 & \left(\psi_{s} \geq \psi_{c}^{\prime}\right)
\end{array}
$$

where $\theta$ is the volumetric soil water content $(\%), \psi$ is the soil water capillary pressure head (cm). Os (the

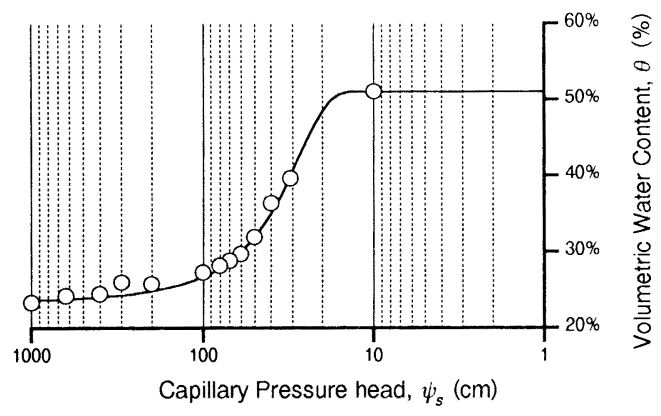

○ Observed $\theta$

Calculated $\theta$

Fig. 2 Relationship between capillary pressure head ( $\phi^{\prime}$ ) and volumetric water content (o) of the soil.

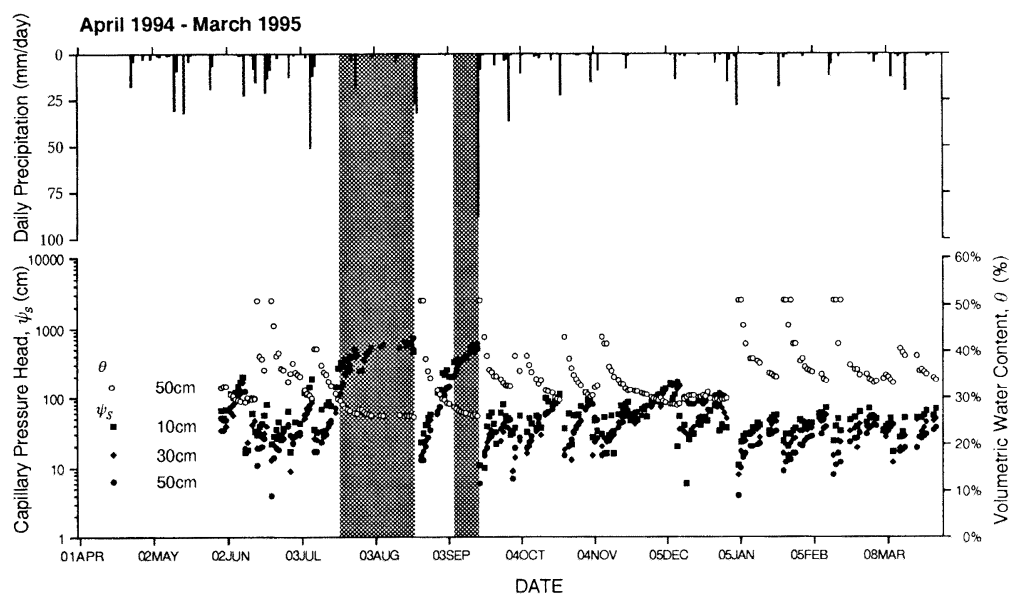

Fig. 3 Seasonal changes of daily precipitation, $\phi^{\prime}$ at $10 \mathrm{~cm}, 30 \mathrm{~cm}, 50 \mathrm{~cm}$ below the soil surface, and 0 at $50 \mathrm{~cm}$ below the soil surface.

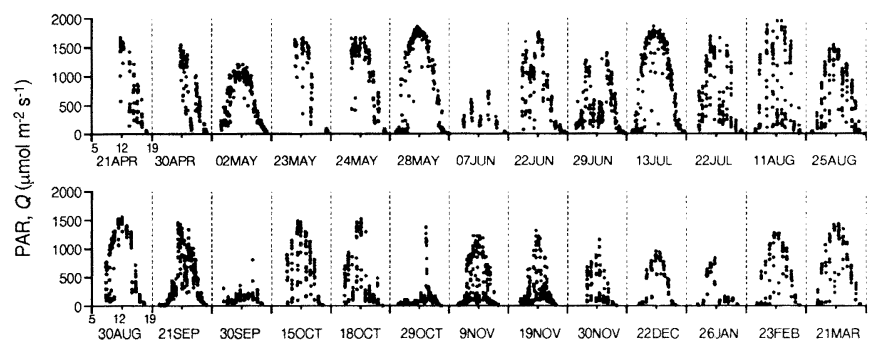

Fig. 4 Diurnal change of PAR $(Q)$ on each observation day (observed with the LI l60(0). 

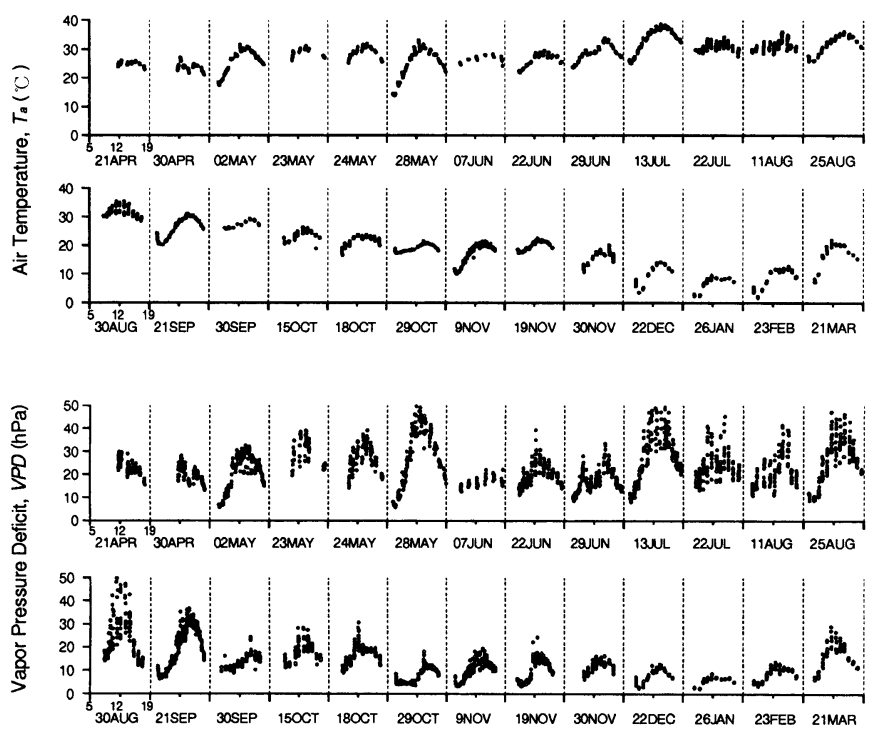

Fig. 5 Diurnal change of air temperature $\left(T_{a}\right)$ and vapor pressure deficit (VPD) on each observation day (observed with the LI-1600).

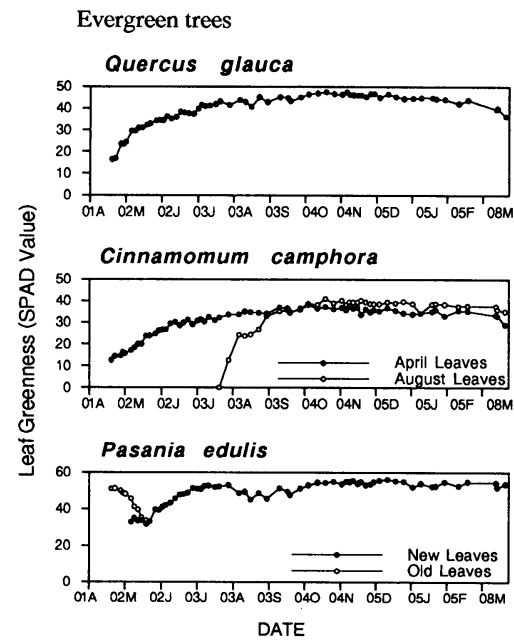

\section{Deciduous trees}
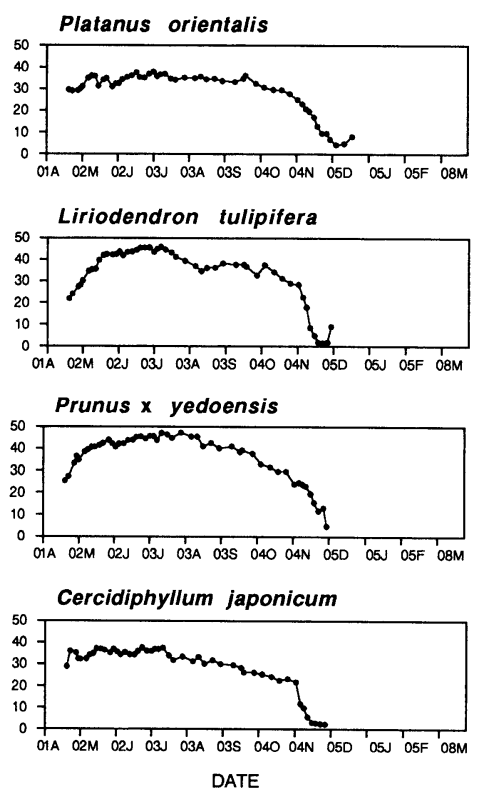

Fig. 6 Seasonal change of average SPAD value of leaves of the seven investigated trees.

saturated volumetric soil water content, $\%)=0.510, \theta_{r}$ (the residual volumetric soil water content, $\left.\%\right)=$ $0.234, \psi_{0}$ (the capillary pressure at the inflection point, $\left.\mathrm{cm}\right)=-23.84, m$ (dimensionless parameter) $=$ 0.5390 and $\psi_{c}$ (the bubbling pressure, $\mathrm{cm}$ ) $=-13.34$.

Fig. 3 shows the seasonal changes of daily precipitation, soil capillary pressure head at $10 \mathrm{~cm}, 30 \mathrm{~cm}$, $50 \mathrm{~cm}$ below the soil surface observed using tensiometers, and soil volumetric water content at $50 \mathrm{~cm}$ 


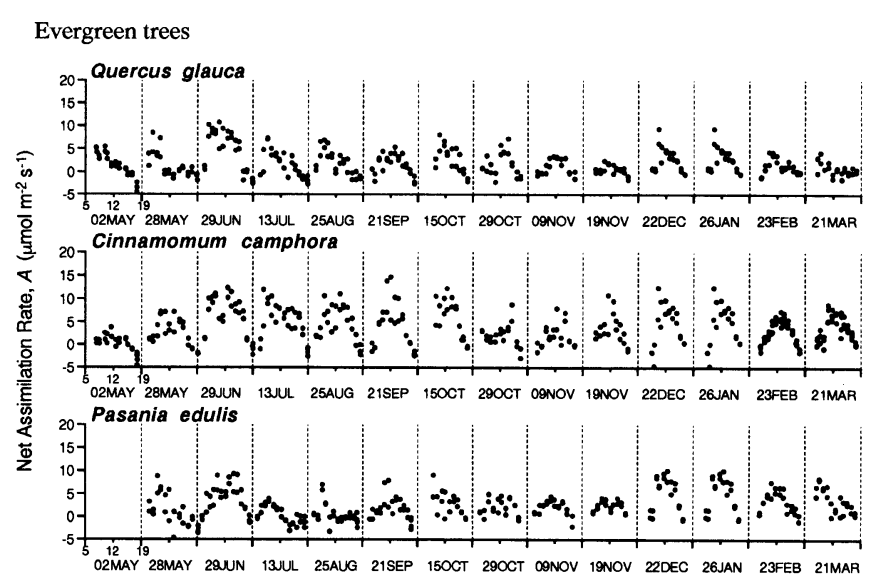

Deciduous trees

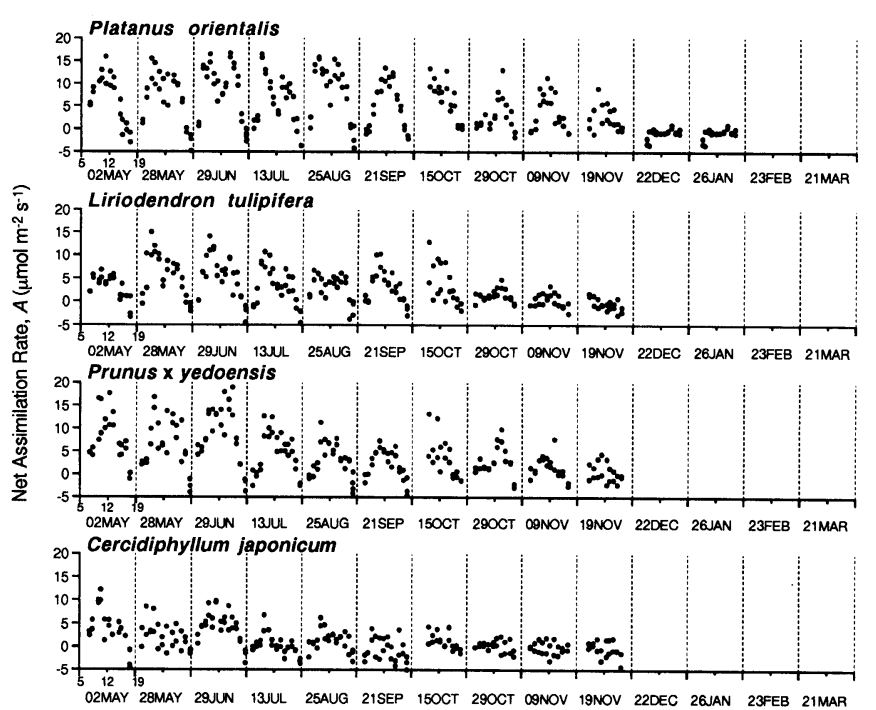

Fig. 7 Diurnal and seasonal change of net assimilation rate $(A)$ of the seven investigated trees (observed with the LI-6200).

below the soil surface calculated with the functional $\theta-\psi_{s}$ curve of this soil (Eq. (1)). During the periods denoted by the gray zones in Fig. 3, the soil around the water uptake zone by root was sometimes very dry with $\psi_{s}<-250 \mathrm{~cm}$. Plants were considered to be under soil drought conditions during these periods.

Fig. 4 shows the diurnal change of PAR on leaves on each observation day. Fig. 5 shows the diurnal change of air temperature and vapor pressure deficit (leaf-to-air vapor pressure difference) in the chamber on each observation day. In these figures, all data which were observed using the LI-1600 are plotted. The maximum value of PAR was around $2000 \mu \mathrm{mol} \mathrm{m} \mathrm{m}^{-2} \mathrm{~s}^{-1}$ in summer and it decreased to around $1000 \mu \mathrm{mol} \mathrm{m}{ }^{-2} \mathrm{~s}^{-1}$ in winter. Air temperature exceeded $35^{\circ} \mathrm{C}$ in summer and reached a minimum value of around $0^{\circ} \mathrm{C}$ on the morning of January 26. Vapor pressure deficit ranged under $50 \mathrm{hPa}$.

Fig. 6 shows the seasonal change of average SPAD value of leaves of the three evergreen and four deciduous trees. The SPAD value of the evergreen trees increased slowly until it reached a plateau in late of June or July, and then remained at the same level until March. In contrast, the SPAD value of the deciduous trees increased rapidly with leaf expansion in April to reach a plateau in May, and the value 

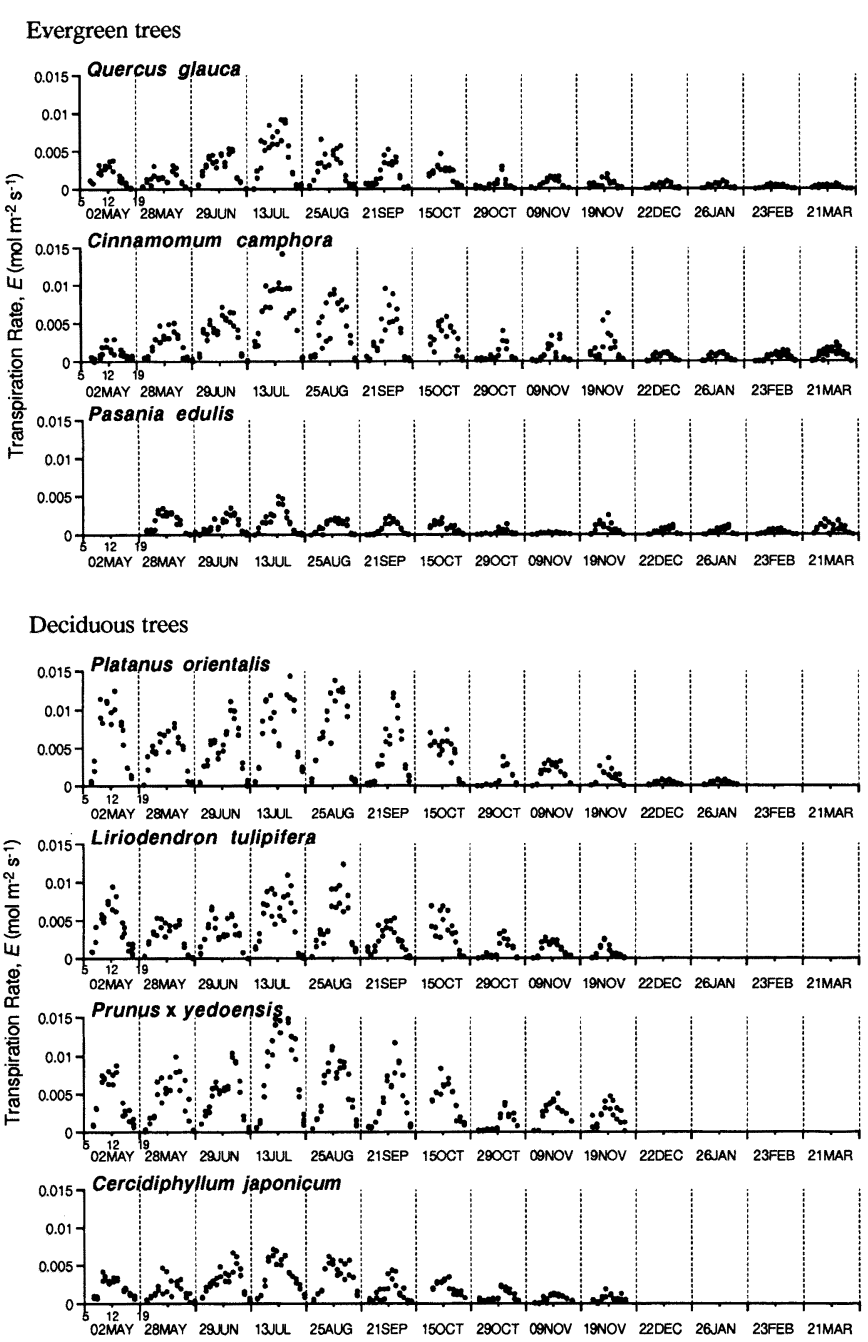

Fig. 8 Diurnal and seasonal change of transpiration rate $(E)$ of the seven investigated trees (observed with the LI-6200).

was only maintained until summer. In some of the deciduous trees (Liriodendron tulipifera, Cercidiphyllum japonicum), a decrease in the SPAD value in summer was observed, which might have been caused by severe soil drought was observed. In autumn, the SPAD value of the deciduous trees decreased rapidly with the coloring of leaves. A similar result was also reported by YoshiKawA et al. (1994). From these results we concluded that evergreen trees take considerable time to make their leaves, but sustain them until next spring. Deciduous trees on the other hand, build up their leaves rapidly after expansion to have high photosynthetic rates during the early stages of their lives, though these leaves are more short-lived than those of evergreen trees.

3.2 Net assimilation rate, transpiration rate and stomatal conductance

Fig. 7 shows the diurnal and seasonal change of net assimilation rate of the seven investigated trees. Fig. 8 shows the diurnal and seasonal change of transpiration rate of the seven investigated trees. Fig. 9 and Fig. 10 show the diurnal and seasonal change of stomatal conductance of the three evergreen trees and the four deciduous trees, respectively.

The essential tendencies, i.e., the peak time of net assimilation rate and transpiration rate in a day, and 


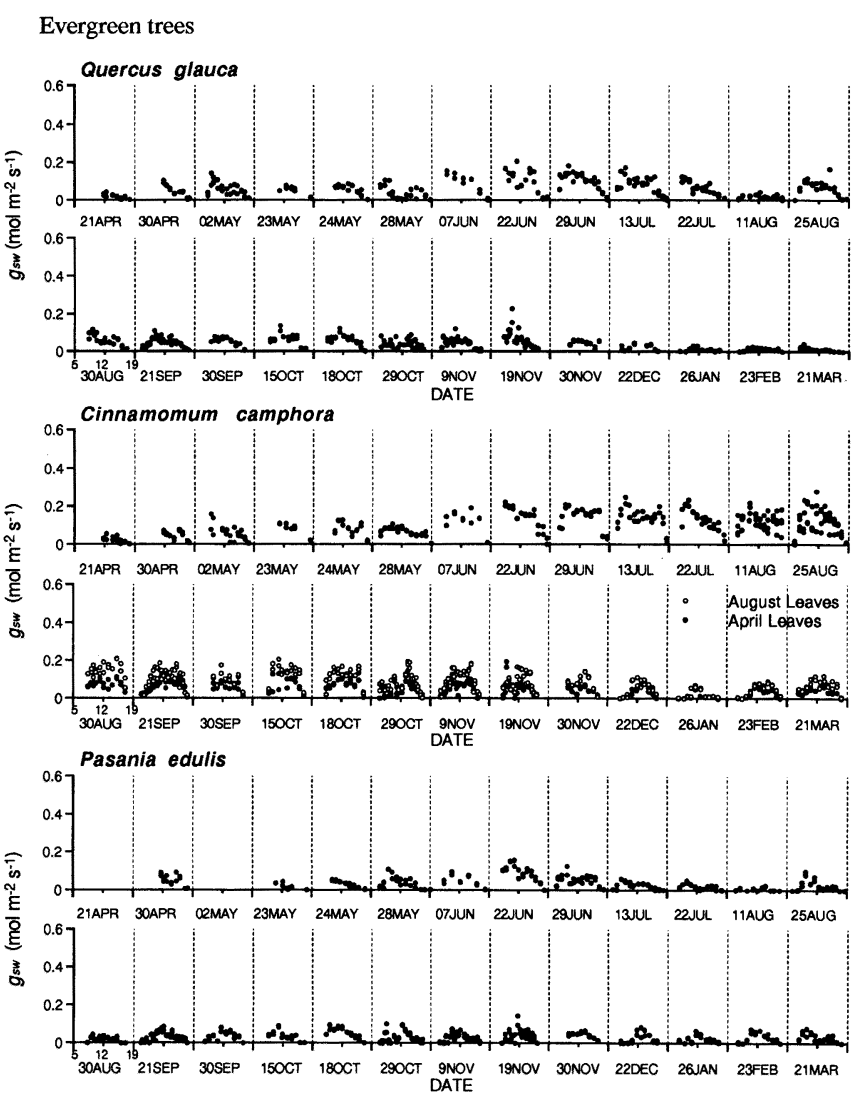

Fig. 9 Diurnal and seasonal change of stomatal conductance $\left(g_{s w}\right)$ of the three evergreen trees (observed with the LI-1600).

the pattern of diurnal change, were similar to those found in KosuGi et al. (1994), which reported that the pattern of transpiration rate had its peak around noon, and that the pattern of net assimilation rate had its peak in the morning. In winter, transpiration rate decreased considerably more than net assimilation rate. This was due to the large change in vapor pressure deficit between summer and winter (see Fig. 5), as investigated in Kosugi et al. (1994). The maximum values of net assimilation rate were around $15-20 \mu \mathrm{mol} \mathrm{m}^{-2} \mathrm{~s}^{-1}$ in the cases of Platanus orientalis, Liriodendron tulipifera and Prunus $\times$ yedoensis, and around 9-14 $\mu \mathrm{mol} \mathrm{m} \mathrm{m}^{-2} \mathrm{~s}^{-1}$ in the cases of Cercidiphyllum japonicum, Quercus glanca, Cinnamomum camphora and Pasania edulis. The maximum values of stomatal conductance were around $0.4-0.6 \mathrm{~mol} \mathrm{~m}^{-2}$ $\mathrm{s}^{-1}$ in the cases of Platanus orientalis, Liriodendron tulipifera and Prunus $\times$ yedoensis and around $0.2 \mathrm{~mol}$ $\mathrm{m}^{-2} \mathrm{~s}^{-1}$ in the cases of Cercidiphyllum japonicum, Quercus glauca, Cinnamomum camphora and Pasania edulis. The maximum net assimilation rate and stomatal conductance of Quercus glauca, Cinnamomum camphora and Pasania edulis were smaller than those of Quercus glauca, Cinnamomum camphora and Pasania edulis of Kosugi et al. (1994). It is guessed from this that the deviations of net assimilation rate, transpiration rate and stomatal conductance caused by the difference in species were not so much larger than the deviations caused by differences in environmental and plant physiological conditions in individual plants.

It is noteworthy that the patterns of seasonal changes of net assimilation rate, transpiration rate, and stomatal conductance of the evergreen trees and the deciduous trees were typical for each other, in spite of the difference in the maximum value with each species. The net assimilation rate of the deciduous 

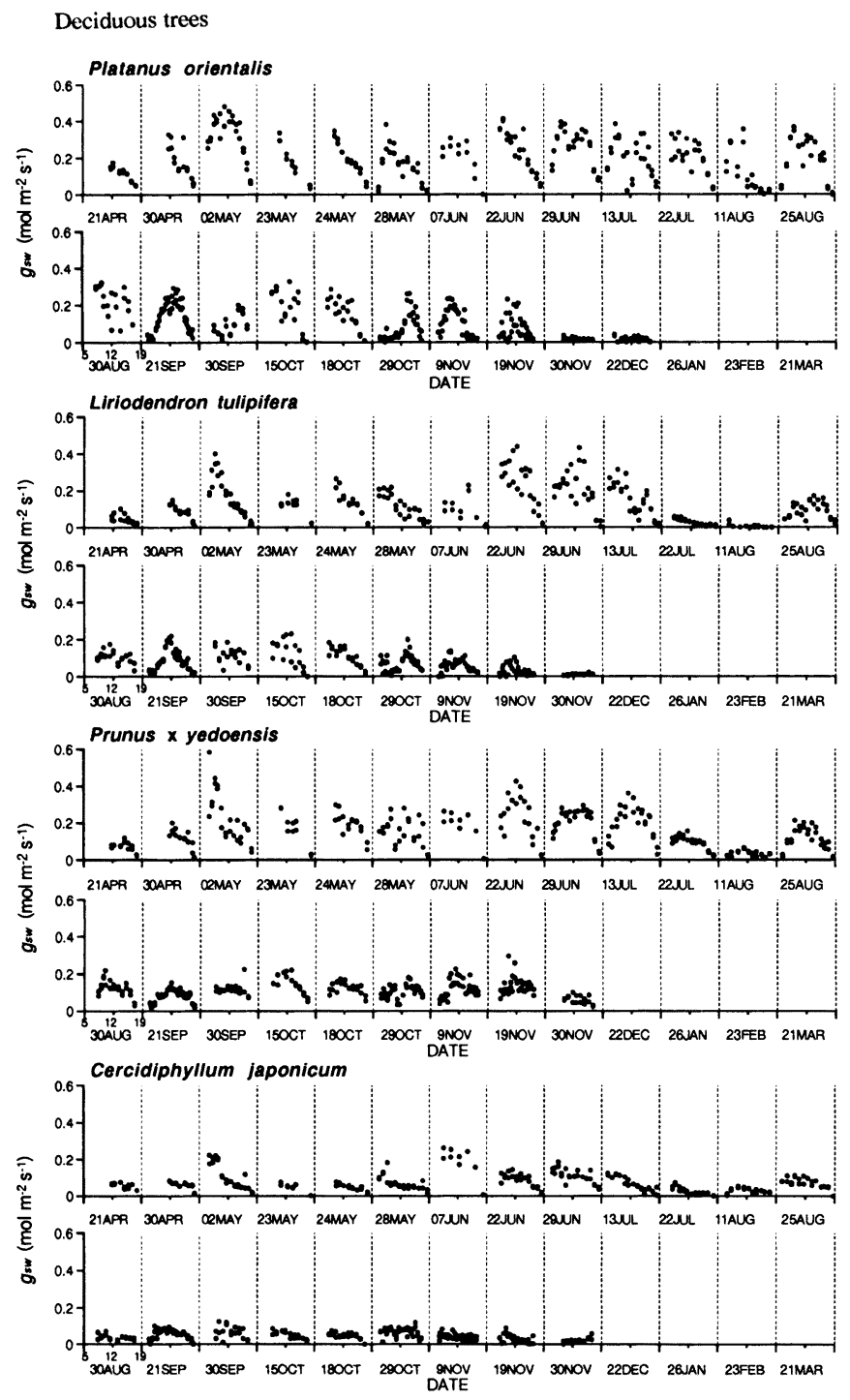

Fig. 10 Diurnal and seasonal change of stomatal conductance $\left(g_{s w}\right)$ of the four deciduous trees (observed with the LI 1600).

trees peaked in early spring and declined rapidly after summer. Although the evergreen trees had a relatively low net assimilation rate with quite suitable environmental conditions in spring, the decline of the net assimilation rate after summer was less than that of deciduous trees.

Stomatal conductance was also small in the three evergreen trees in spring and early summer. Stomatal conductance reached its maximum value in the four deciduous trees during the same season. After summer the stomatal conductance of the four deciduous trees declined more rapidly than that of the three evergreen trees.

These seasonal patterns were similar to the pattern of net assimilation rate and SPAD value. As both stomatal opening, which decides transpiration rate with vapor pressure deficit, and activity of photosynthesis are driven by the energy of radiation using the system of electron transport in chlorophyll (Pemadasa, 1982; Zeigier et al. 1981; Zeiger, 1983), it is quite natural that the chlorophyll content 
influences both stomatal conductance and net assimilation rate.

\section{Conclusions}

Several typical characteristics in the patterns of the diurnal and seasonal changes of net assimilation rate, transpiration rate and stomatal conductance were identified from the results of the observation. The deviations of net assimilation rate, transpiration rate and stomatal conductance attributable to the differences in species seemed not so much greater than the deviations caused by differences in environmental and plant physiological conditions in individual plants. The patterns of the seasonal changes of net assimilation rate, transpiration rate and stomatal conductance were different among deciduous trees and evergreen trees. The net assimilation rate and stomatal conductance of the deciduous trees peaked in early spring and declined rapidly after summer. The evergreen trees had a relatively low net assimilation rate and stomatal conductance with quite suitable environmental conditions in spring, though the decline after summer was less than that of deciduous trees. The differences in the seasonal patterns of net assimilation rate and stomatal conductance correspond to the differences in the patterns of the seasonal changes of leaf chlorophyll content. From these results we conclude that the change of chlorophyll content must be monitored in addition to several environmental variables in order to simulate the long-term change of photosynthesis and transpiration of long-sustained leaves.

\section{References}

HAN, Q. and KAKUBARI, Y.: Diurnal and seasonal courses of photosynthesis, transpiration and water use efficiency of apple and black locust seedlings in different soil water conditions. J. Jap. Soc. Reveget. Tech. 21, 114-123, 1995

Kobayashi, T., TAGA, A. OKinaKa, T.: The effects of flooding on water relations, photosynthesis and growth of four tree species with different site preferences. J. Jap. Soc. Reveget. Tech. 20, 150-157, 1995

KosUGI, K. : Three-parameter lognormal distribution model for soil water retention. Water Resour. Res. 30, 891 $-901,1994$

KosUgi, Y., KoBASHI, S. and SHibATA, S. : Analysis on diurnal and seasonal variation pattern of transpiration and net assimilation rate of several evergreen broad-leaved trees. J. Jap. Soc. Reveget. Tech. 19, 245-255, 1994 (in Japanese)

KosUGi, Y. and KoBASHI, S. : Transpiration, photosynthesis, and stomatal conductance on leaves of several temperate broad-leaved trees under the regulation of environmental and physiological factors. Proceedings of the International Symposium on Forest Hydrology, Tokyo, Japan, 139-146, 1994

Kosugi, Y., Kobashi, S. and Shibata, S. : Modeling stomatal conductance on leaves of several temperate evergreen broad-leaved trees. J. Jap. Soc. Reveget. Tech. 20, 158-167, 1995 (in Japanese)

MASUDA, T. and ISHII, M. : A fundamental study on the method for estimating tree vigor-Reflection spectra and chlorophyll contents in tree leaves. Bulletin of Revegetation Research 7, 1-11, 1985 (in Japanese)

MASUdA, T., MORIYA, H. and KATAYAma, K. : Soil condition and growth of the camphor trees in Sakaide green belt (II) - photosynthesis and transpiration - J. Jap. Soc. Reveget. Tech. 16(3), 19-30, 1991 (in Japanese)

MASUDA, T., KURISAKA, K. and MORIYA, H. : Seasonal changes of photosynthetic rate and transpiration rate of tulip tree (Liriodendron tulipifera) planted on different soil conditions. J. Jap. Soc. Reveget. Tech. 19, 223 $-233,1994$ (in Japanese)

PEMADASA M.A. : Abaxial and adaxial stomatal responses to light of different wavelengths and to phenylacetic acid on isolated epidermis of Commelina commumus L. J. Exp. Bot. 33, 92-99, 1982

SHIBATA, S., KoBASHI, S. and HANAYAMA, H. : Influence of soil moisture and air temperature to photosynthetic activity of some ever-green broad-leaved trees. J. Jap. Soc. Reveget. Tech. 17, 1-8, 1991 (in Japanese)

Tobias, D.J., Yoshikawa, K., IKemoto, A. and YamaGuchi, Y.: Seasonal changes of leaf chlorophyll content in the crowns of several broad-leaved tree species. J. Jap. Soc. Reveget. Tech. 20, 21-32, 1994

Yoshikawa, K., Inoue, Y., Shima, K., Chiba, K. and SAKamoto, K.: Seasonal changes in leaf chlorophyll contents of tree species. J. Jap. Soc. Reveget. Tech. 19, 215-222, 1994 (in Japanese)

VAN GENUCHTEN, M.T.: A closed-form equation for predicting the hydraulic conductivity of unsaturated soils. Soil Sci. Soc. Am. J. 44, 892-898, 1980

ZEIGER, E., ARMOND, P. and MELIS, A. : Fluorescence properties of guard cell chloroplasts. Evidence for linear 
electron transport and light-harvesting pigments of photosystems I and II. Plant physiol. 67, 17-20, 1981 ZEIGER, E. : The biology of stomatal guard cells. Ann. Rev. Plant Physiol. 34, 441-475, 1983

(1997.2.10 accepted)

要旨

温帯性落葉広葉樹と常緑広葉樹における, 個葉の光合成速度・蒸散速度・気孔コンダクタンスの季節変動特 性を比較するために, 野外観測を行った。観測の結果, 落葉広葉樹では光合成速度および気孔コンダクタンス が展開後早い時期にピークを持ち, 夏以降急激に減少する一方, 常緑広葉樹では春の光合成速度および気孔コ ンダクタンスが最適な環境条件の割に低く, 定常に達するのは遅いが, 秋から冬にかけての減少は落葉広葉樹 ほど急激ではないという傾向が検出された。この傾向はクロロフィル濃度の変化と密接な関係があると考えら れている SPAD 值の季節変動特性と連動するものであった。 